\title{
Influence of lifestyle characteristics and VDR polymorphisms as risk factors for intervertebral disc degeneration: a case- control study
}

\author{
Luiz Angelo Vieira', Aline Amaro dos Santos², Carla Peluso², Caio Parente Barbosa ${ }^{3}$, Bianca Bianco ${ }^{2,3^{*}}$ \\ and Luciano Miller Reis Rodrigues ${ }^{1}$
}

\begin{abstract}
Background: Intervertebral disc degeneration (DD) is an important cause of low back pain and its precise aetiology is not fully understood, being attributed to cumulative environmental, biomechanical and genetic effects. The vitamin D plays a key role in regulation of calcium homeostasis and bone mineralization, exerting its biological activities by binding to a high-affinity receptor (VDR). Polymorphisms in VDR gene were previously associated with DD process, however with conflicting results. Here, we aimed to investigate the influence of lifestyle characteristics and VDR Taql, Bsml, Apal and Fokl polymorphisms as risk factors for DD process.

Methods: Retrospective case-control study involving 231 participants: 119 with confirmed DD and 112 healthy controls. Genotyping of VDR polymorphisms was performed by PCR-RFLP and real-time PCR using TaqMan methodology. All patients answered a questionnaire regarding lifestyle characteristics, such as educational level, pain localization, smoking habits, engagement of physical activity, postural and load weight at work and familial history of disc degeneration. The variables were compared between groups and adjusted by age and gender.

Results: The case group was composed by $52 \%$ female and $48 \%$ male and the mean age was 40.0 years old, while in the control group $79 \%$ was female and $21 \%$ male and the mean age was 32.0 years old. Although gender distribution and mean age were different between groups, in the control group all participants were less than 45 years old and there was a prevalence of women in both groups. The factors that could be possibly associated to DD in the Brazilian population studied included smoking habits ( $26 \%$ in cases and $9 \%$ in controls, $p=0.003$ ), lack of engagement in physical activity (observed in $77 \%$ of cases and $62 \%$ of controls, $p=0.018$ ), and loading weight during work routine ( $58 \%$ in cases and $24 \%$ in controls, $p \leq 0.001$ ). However, after adjusting by age and gender, only smoking habits remained associated to disc degeneration $(p=0.027)$. Considering the educational level, $35.2 \%$ of cases and $15.6 \%$ of controls had only the Elementary School, and 5.5\% of DD group and $28.6 \%$ of control group had completed College $(p=0.025)$. In addition, educational level was directly associated to load weight at work $(p=0.012)$. Regarding VDR polymorphisms, no significant difference in genotype and allele frequencies between groups was observed. The haplotype analysis revealed that the combined wild-type alleles of Taql, Apal and Fokl polymorphisms-TGT_was observed in a higher frequency in control group $(p=0.039)$.
\end{abstract}

\footnotetext{
*Correspondence: bianca.bianco@fmabc.br

2 Laboratory of Genetics, Human Reproduction and Genetics Center,

Faculdade de Medicina do ABC, Av. Lauro Gomes, 2000, Santo André, SP

CEP 09060-870, Brazil

Full list of author information is available at the end of the article
} 
Conclusion: The findings suggested that smoking habits was a risk factor for disc degeneration in the population studied. Single analysis revealed no significant effects of VDR polymorphisms in disc degeneration process, while the combination of wild-type alleles of Taql, Apal and Fokl polymorphisms, TGT haplotype, decreased the risk of the disease.

Keywords: Disc degeneration, VDR, Back pain, Polymorphism

\section{Background}

The physiological process that induces intervertebral disc degeneration (DD) is thought to be primarily due to the interaction between the loads deposited on the discs and advanced age. However, disc degeneration processes can be observed in young adults, and the pathways likely differ among age groups. The relationships among the main clinical conditions, low back pain in adults, and non-agerelated disc issues need to be studied to clarify the steps for determining the physiological processes and pathways that maintain healthy intervertebral discs [1]. The pathogenesis of lumbar disc degeneration includes radial fissures, rim tears in the annulus, and loss of water content in the nucleus pulpous and annulus. These changes are suspected of underlying many back pain symptoms $[2,3]$.

Disc degeneration is a multifactorial condition, and although the events leading to DD are not well understood, the outcome of studies over the last decade has shown that genetic influence plays a large role in DD process, together with environmental factors that include body mass index (BMI), work postures, heavy physical loading and smoking habits, however their effect is moderate in comparison to heredity $[4,5]$.

Understanding of the genetic profile is an important tool that may aid therapy and diagnosis; however, this process demands extensive research because small changes in DNA sequences can lead to cellular or microenvironmental disequilibria. In the bone, vitamin $\mathrm{D}$ is important to maintain the balance between calcium absorption and bone matrix mineralization, reducing fracture risk by improving bone mineral density [6]. Nevertheless, it remains unclear how the concentrations and absorption pathways vary among different in vivo and in vitro studies [7].

It has been postulated that the maintenance of bone mineral density occurs via the stimulation of intestinal calcium and phosphate absorption [8]. The majority of the biological activities of vitamin $\mathrm{D}$ are mediated by a high-affinity receptor that acts as a transcription factor and is activated by a ligand, i.e., the vitamin $\mathrm{D}$ receptor, which is encoded by the $V D R$ gene at 12q13.11. Genetic alterations in the $V D R$ gene lead to significant gene activation defects that affect calcium metabolism, cell proliferation, immune function and other processes, yet these changes can be explained by alterations in protein conformation or gene expression [9].

$V D R$ was the first reported gene associated with $\mathrm{DD}$ risk in a study of monozygotic twins in Finns [10]. Since then, there have been many studies with conflicting results ranging from strong links to no association. The divergent results regarding the effects of $V D R$ genetic polymorphisms upon DD risk may be attributed mainly to the differences in racial origin of the population studied [11]. The heterogeneity among populations occurs due to different genetic ancestries. This is especially important in admixed populations, such as the Brazilian population, which is known to be one of the most heterogeneous populations in the world, with contributions from three main parental groups: Amerindian, European and African [12, 13]. Hence, Brazilian population could show different results than those presented in non-mixed populations.

Here, we aimed to investigate the possible influence of lifestyle characteristics and VDR TaqI, BsmI, ApaI and FokI polymorphisms as risk factors for disc degeneration process.

\section{Methods \\ Subjects}

A retrospective case-control study was conducted involving 231 Brazilian patients: 119 patients in follow up of the Outpatient Clinic of the Spinal Surgery at the Hospital Estadual Mário Covas of the Faculdade de Medicina do $\mathrm{ABC}$, Santo André/SP, Brazil. The inclusion criteria were: (i) patients with chronic low back pain (over 3 months), (ii) aged $<45$ years, and (iii) with magnetic resonance imaging (MRI) evidencing DD with Pfirrmann classification [14] with grades 3,4 or 5 on sagittal T2. The exclusion criteria were: (i) patients who have undergone previous surgical treatment, (ii) with congenital deformities of the spine, or (iii) who refuse to sign the consent form and donate a blood sample for analysis of genomic DNA.

The MRI scans of all patients were performed by two experienced radiologists and the images were evaluated by an orthopedic spine surgeon. The degree of DD was graded from T2-weighted images according to Pfirrmann classification [14], and only patients with grades 3,4 , or 
5 were included in the case group, once moderate and intense DD is evident.

Considering the control group, 112 healthy patients were recruited in the Clinical Laboratory of Faculdade de Medicina do $A B C$ and the inclusion criteria were: (i) aged 20-45 years old, (ii) without previous surgery, (iii) no history of disc hernia treatment, (iv) who have not been hospitalized for back pain, (v) not taking medication for back pain for more than 7 days, and (vi) not having family members younger than 45 years with disc herniation and/or clinical treatment for low back pain.

\section{Lifestyle evaluation}

All study subjects answered a clinical and epidemiological questionnaire instrument that included age, gender, occupation, education level, weight, height, smoking habits (yes or no) and information regarding complaints, pain (low back, cervical or both), familial history (yes or no), physical activity (at least 90 min per week) and postural (seated or standing) and load weight at work (yes or no). Questionnaires were implemented via face-to-face interviews conducted by researchers of this study.

The body mass index (BMI) was calculated for each subject as BMI $=$ weight $[\mathrm{kg}] /$ height $\left[\mathrm{m}^{2}\right]$.

\section{Molecular analyses}

The methods were previously described [15]. Briefly, the DNA was extracted according to protocols of Lahiri and Nurnberger [16]. The DNA was quantified and diluted to achieve a uniform final concentration of $50 \mathrm{ng} / \mu \mathrm{L}$. The VDR genotyping for the TaqI/T $>6 \mathrm{C} / \mathrm{rs} 731236$, ApaI/G>T/rs11168271 and FokI/T>C/10735810 polymorphisms was performed using polymerase chain reaction-restriction fragment length polymorphism method. PCR products were digested with appropriate restriction enzymes (New England Biolabs ${ }^{\circledR}$, Ipswich, MA, USA) and the resultant solutions were submitted to electrophoresis on a $2 \%$ agarose gel. BsmI/G>A/ rs15444410 polymorphism were identified by real-time PCR using TaqMan methodology from Thermo Fisher Scientific ${ }^{\circledR}$ (Waltham, Massachusetts, EUA), following the conditions recommended by the manufacturer.

\section{Statistical analyses}

The statistical analyses were performed with Stata ${ }^{\circledR}$ software (SE 11.0) for Windows. To evaluate the characteristics that could be possible risk factors for disc degeneration, the qualitative variables were analysed using Chi square test, while Mann-Whitney test was used for the quantitative variables. After identifying the variables that were associated with disc degeneration, such factors were analysed using logistic regression adjusted by age and gender.
To detect differences in allele and genotype frequencies of the $V D R$ polymorphism between disc degeneration group and controls, the logistic regression was used, also adjusted by age and gender. To estimate the HardyWeinberg equilibrium (HWE), as well as to compare inheritance patterns (dominant or recessive models) of the polymorphisms studied between groups, the Chisquare test was used as well.

The odds ratio (OR) and confidence interval were used to measure the strength of the association between the frequencies of $V D R$ genotypes and disc degeneration. All $p$-values were two-tailed, and 95\% confidence intervals (CIs) were calculated. The association between the combined alleles of $V D R$ polymorphisms and the risk of disc degeneration were evaluated using Haploview software version 4.1, available at http://www.hapmap.org. A $p$ value $<0.05$ was considered statistically significant.

\section{Results}

The characteristics of disc degeneration group and controls, including age, gender, BMI, educational level, pain localization, smoking habits, engagement of physical activity, postural and load weight at work are shown in Table 1 . The case group was composed by $52 \%$ female and $48 \%$ male and the mean age was $40.0(38.0 ; 42.0)$ years old, while in the control group $79 \%$ was female and $21 \%$ male and the mean age was $32.0(31.0 ; 35.0)$ years old. Although the median age and proportions of female and male participants were different between groups, all participants were less than 45 years old and there was a prevalence of women in both groups. Therefore, to avoid bias the comparisons between groups, they were adjusted by age and gender.

The factors that can be possibly associated to disc degeneration in the Brazilian population studied were smoking habits, $26 \%$ of the DD group were smoker versus $9 \%$ of the control group $(p=0.003)$; loading weight during work routine, present in $58 \%$ of the DD group versus $24 \%$ of the control group ( $p<0.001)$; and lack of engagement in physical activity, once it was observed in $23 \%$ of the DD group versus $38 \%$ of the control group $(p=0.018)$. However, after adjusting age and gender, only smoking habits remained associated to disc degeneration $(p=0.027)$.

Moreover, considering the educational level, $35.2 \%$ of the disc degeneration group had only Elementary School compared with $15.6 \%$ of the control group; for High School level, both groups presented similar proportions of participants who had completed this level $(59.3 \%$ in confirmed cases and $57.3 \%$ in control group), and just $5.5 \%$ of participants in the DD group had completed College compared with $27.1 \%$ of participants in the control group, $p=0.025$. In addition, we associated the 
Table 1 Characterization of studied groups

\begin{tabular}{|c|c|c|c|c|c|}
\hline Characteristics & DD & Control & $p$-value* & Adjusted OR (95\% Cl) & $p$-value ${ }^{a}$ \\
\hline \multicolumn{6}{|l|}{ Gender } \\
\hline Male & $57(48 \%)$ & $23(21 \%)$ & $<0.001$ & Ref. $^{a}$ & Ref. \\
\hline Female & $62(52 \%)$ & $89(79 \%)$ & & $0.22(0.11-0.44)$ & $<0.001$ \\
\hline \multicolumn{6}{|l|}{ Educational level } \\
\hline Elementary school & $32(35.2 \%)$ & $15(15.6 \%)$ & 0.002 & Ref. & Ref. \\
\hline High school & $54(59.3 \%)$ & $55(57.3 \%)$ & 0.776 & $1.12(0.47-2.71)$ & 0.789 \\
\hline College & $5(5.5 \%)$ & $26(27.1 \%)$ & $<0.001$ & $0.22(0.06-0.83)$ & 0.025 \\
\hline \multicolumn{6}{|l|}{ Pain localization } \\
\hline Low back & $86(93.5 \%)$ & - & - & - & - \\
\hline Low back + cervical & $6(6.5 \%)$ & & & & \\
\hline \multicolumn{6}{|l|}{ Smoker } \\
\hline No & $70(74 \%)$ & 87 (91\%) & 0.003 & Ref. & \\
\hline Yes & $24(26 \%)$ & $9(9 \%)$ & & $2.84(1.13-7.68)$ & 0.027 \\
\hline \multicolumn{6}{|l|}{ Physical activity } \\
\hline No & $92(77 \%)$ & $60(62 \%)$ & 0.018 & Ref. & \\
\hline Yes & $27(23 \%)$ & $36(38 \%)$ & & $0.64(0.32-1.27)$ & 0.204 \\
\hline \multicolumn{6}{|l|}{ Posture at work } \\
\hline Seated & $29(33 \%)$ & $22(26 \%)$ & 0.285 & Ref & \\
\hline Standing & $58(67 \%)$ & $63(74 \%)$ & & $0.38(0.17-0.84)$ & 0.170 \\
\hline \multicolumn{6}{|l|}{ Load weight at work } \\
\hline No & $37(42 \%)$ & $73(76 \%)$ & $<0.001$ & Ref. & \\
\hline Yes & $51(58 \%)$ & $23(24 \%)$ & & $2.00(0.95-4.20)$ & 0.066 \\
\hline \multirow[t]{2}{*}{ Characteristics } & DD & Control & $p$-value* & Adjusted OR (95\% Cl) & $p$-value ${ }^{a}$ \\
\hline & Median $(95 \% \mathrm{Cl})$ & & & & \\
\hline Age (years old) & $40.0(38.0 ; 42.0)$ & $32.0(31.0 ; 35.0)$ & $<0.001^{* *}$ & $1.12(1.07-1.18)$ & $<0.001$ \\
\hline BMI & $25.9(25.2 ; 27.0)$ & $25.4(24.5 ; 26.6)$ & $0.643^{* *}$ & $0.99(0.92-1.07)$ & 0.837 \\
\hline
\end{tabular}

$D D$ intervertebral disc degeneration, $\mathrm{Cl}$ confidence interval, $B M I$ body mass index

* Chi square test

a Adjusted for age and gender

a Mann-Whitney test

educational level with position at work (seated or standing) and no difference was found between the groups $(p=0.106)$. However, the educational level was positively associated to load weight at work, being present in $75.9 \%$ of the DD group and $46.7 \%$ of the control group that had only Elementary School ( $p=0.053), 49.0 \%$ of the DD group and $27.3 \%$ of the control group that had completed High School $(p=0.021)$, and only $3.9 \%$ of the patients with DD had completed College and $40 \%$ of the controls $(p=0.012)$.

Regarding VDR polymorphisms, the genotype and allele frequencies of the TaqI, BsmI, ApaI and FokI polymorphisms in disc degeneration and control groups are shown in Table 2. The single-marker analysis revealed no significant difference between groups in the genotypes and allele frequencies for all polymorphisms studied: TaqI, BsmI $(p=0.824$, OR $=1.05$, $95 \% \mathrm{CI}=0.70-1.57)$, ApaI ( $p=0.486$, OR $=1.14,95 \%$
$\mathrm{CI}=0.79-1.66)$ and FokI $(p=0.076$, OR $=1.43,95 \%$ $\mathrm{CI}=0.96-2.13)$. The genotype frequencies of ApaI and FokI polymorphisms of the DD and control groups were in Hardy-Weinberg equilibrium; however, the deviation of HWE was observed in DD group considering TaqI polymorphism, and both DD and control groups were related to BsmI polymorphism.

The inheritance patterns of the VDR polymorphism were also evaluated and the TaqI polymorphism exhibited a significant difference in the recessive model $(p=0.042)$ between groups, whereas two polymorphic alleles $(\mathrm{CC})$ are necessary to predispose a higher risk for disc degeneration. The BsmI, FokI and ApaI polymorphisms did not reveal any significant difference in inheritance patterns between groups (Table 3).

To further explore the effect of the combined alleles of $V D R$ polymorphisms, we performed a haplotype 
Table 2 Genotype and allele frequencies of Taql, Bmsl, Apal and Fokl polymorphisms of the VDR gene in intervertebral disc degeneration and control group

\begin{tabular}{|c|c|c|c|c|c|c|c|c|c|c|}
\hline \multirow[t]{2}{*}{ VDR SNPs } & \multirow[t]{2}{*}{ Population } & \multirow[t]{2}{*}{$N$} & \multicolumn{7}{|c|}{ Genotypes } & \multirow[t]{2}{*}{ HWE } \\
\hline & & & $n(\%)$ & $n(\%)$ & $p^{*}$ & OR $(95 \% \mathrm{Cl})$ & $n(\%)$ & $p^{*}$ & OR $(95 \% \mathrm{Cl})$ & \\
\hline \multirow{3}{*}{$\begin{array}{l}\text { Taql } \\
\text { T>C }\end{array}$} & & & $\mathrm{TT}$ & $\mathrm{TC}$ & & & CC & & & \\
\hline & $\mathrm{DD}$ & 119 & $50(42 \%)$ & $42(35 \%)$ & & Ref. & $27(23 \%)$ & Ref. & Ref. & 0.015 \\
\hline & Controls & 112 & $52(46 \%)$ & $46(41 \%)$ & 0.858 & $0.95(0.54-1.68)$ & $14(13 \%)$ & 0.067 & $2.01(0.94-4.26)$ & 0.750 \\
\hline \multirow{3}{*}{$\begin{array}{l}\text { Bsml } \\
G>A\end{array}$} & & & GG & GA & & & $\mathrm{AA}$ & & & \\
\hline & DD & 119 & $52(44 \%)$ & $67(56 \%)$ & & Ref. & $0(0 \%)$ & - & - & $<0.001$ \\
\hline & Controls & 112 & $51(46 \%)$ & $61(54 \%)$ & 0.778 & $1.08(0.64-1.81)$ & $0(0 \%)$ & & & $<0.001$ \\
\hline \multirow{3}{*}{$\begin{array}{l}\text { Apal } \\
G>T\end{array}$} & & & GG & GT & & & $\mathrm{TT}$ & & & \\
\hline & DD & 119 & 37 (31\%) & $64(54 \%)$ & & Ref. & $18(15 \%)$ & Ref. & Ref. & 0.527 \\
\hline & Controls & 112 & $39(35 \%)$ & $59(53 \%)$ & 0.645 & $1.14(0.65-2.03)$ & $14(12 \%)$ & 0.472 & $1.36(0.59-3.11)$ & 0.515 \\
\hline \multirow{3}{*}{$\begin{array}{l}\text { Fokl } \\
T>C\end{array}$} & & & $\mathrm{TT}$ & $\mathrm{TC}$ & & & $\mathrm{CC}$ & & & \\
\hline & DD & 119 & $53(44.5 \%)$ & $49(41.2 \%)$ & & Ref. & $17(14.3 \%)$ & Ref. & Ref. & 0.595 \\
\hline & Controls & 112 & 61 (54.5\%) & 41 (36.6\%) & 0.259 & $1.38(0.79-2.040)$ & 10 (8.9\%) & 0.123 & $1.96(0.83-4.64)$ & 0.722 \\
\hline \multirow[t]{2}{*}{ VDR SNPs } & Population & $N$ & Alleles & & & & & & & \\
\hline & & & $n(\%)$ & $n(\%)$ & $p^{*}$ & OR $(95 \% \mathrm{Cl})$ & & & & \\
\hline \multirow{3}{*}{$\begin{array}{l}\text { Taql } \\
\text { T>C }\end{array}$} & & & $\mathrm{T}$ & $C$ & & & & & & \\
\hline & $\mathrm{DD}$ & & $142(59.7)$ & $96(40.3)$ & & Ref. & & & & \\
\hline & Controls & & $150(67.0)$ & $74(33.0)$ & 0.103 & $1.37(0.94-2.00)$ & & & & \\
\hline \multirow{3}{*}{$\begin{array}{l}\text { Bsml } \\
G>A\end{array}$} & & & G & A & & & & & & \\
\hline & $\mathrm{DD}$ & & $171(71.8)$ & $67(28.2)$ & & Ref. & & & & \\
\hline & Controls & & $163(72.8)$ & $61(27.2)$ & 0.824 & $1.05(0.70-1.57)$ & & & & \\
\hline \multirow{3}{*}{$\begin{array}{l}\text { Apal } \\
G>T\end{array}$} & & & G & $\mathrm{T}$ & & & & & & \\
\hline & DD & & $138(58.0)$ & $100(42.0)$ & & Ref. & & & & \\
\hline & Controls & & $137(61.2)$ & $87(38.8)$ & 0.486 & $1.14(0.79-1.66)$ & & & & \\
\hline \multirow{3}{*}{$\begin{array}{l}\text { Fokl } \\
\text { T>C }\end{array}$} & & & $\mathrm{T}$ & C & & & & & & \\
\hline & DD & & $155(65.1)$ & $83(34.9)$ & & Ref. & & & & \\
\hline & Controls & & 163 (72.8) & $61(27.2)$ & 0.076 & $1.43(0.96-2.13)$ & & & & \\
\hline
\end{tabular}

$D D$ intervertebral disc degeneration, SNPs single nucleotide polymorphism, OR odds ratio, Cl confidence interval, HWE Hardy-Weinberg equilibrium Ref. Reference category

* Chi square test

Table 3 Recessive and dominant models considering the Taql, Bmsl, Apal and Fokl polymorphisms of the VDR gene in intervertebral disc degeneration and control group

\begin{tabular}{|c|c|c|c|c|c|c|c|c|}
\hline & \multicolumn{8}{|c|}{ VDR polymorphisms } \\
\hline & \multicolumn{2}{|l|}{ Taql } & \multicolumn{2}{|l|}{ Bsml } & \multicolumn{2}{|l|}{ Apal } & \multicolumn{2}{|l|}{ Fokl } \\
\hline & $\begin{array}{l}\text { Recessive } \\
\text { model } \\
\text { TT + TC x CC } \\
N(\%)\end{array}$ & $\begin{array}{l}\text { Dominant } \\
\text { model } \\
\text { TT } \times \text { TC }+ \text { CC } \\
N(\%)\end{array}$ & $\begin{array}{l}\text { Recessive } \\
\text { model } \\
\text { GG + GA } \times \text { AA } \\
N(\%)\end{array}$ & $\begin{array}{l}\text { Dominant } \\
\text { model } \\
\text { GG } \times \text { GA + AA } \\
N(\%)\end{array}$ & $\begin{array}{l}\text { Recessive } \\
\text { model } \\
\text { GG + GT } \times \text { TT } \\
N(\%)\end{array}$ & $\begin{array}{l}\text { Dominant } \\
\text { model } \\
\text { GG } \times \text { GT + TT } \\
N(\%)\end{array}$ & $\begin{array}{l}\text { Recessive } \\
\text { model } \\
\text { TT + TC x CC } \\
N(\%)\end{array}$ & $\begin{array}{l}\text { Dominant } \\
\text { model } \\
\text { TT } \times \text { TC + CC } \\
N(\%)\end{array}$ \\
\hline DD group & $\begin{array}{l}92 \times 27 \\
77 \% \times 23 \%\end{array}$ & $\begin{array}{l}50 \times 69 \\
42 \% \times 58 \%\end{array}$ & $\begin{array}{l}119 \times 0 \\
100 \% \times 0 \%\end{array}$ & $\begin{array}{l}52 \times 67 \\
44 \% \times 56 \%\end{array}$ & $\begin{array}{l}101 \times 18 \\
85 \% \times 15 \%\end{array}$ & $\begin{array}{l}37 \times 82 \\
31 \% \times 69 \%\end{array}$ & $\begin{array}{l}102 \times 17 \\
85.7 \% \times 14.3 \%\end{array}$ & $\begin{array}{l}53 \times 66 \\
44.5 \% \times 55.5 \%\end{array}$ \\
\hline $\begin{array}{l}\text { Control } \\
\text { group }\end{array}$ & $\begin{array}{l}98 \times 14 \\
87 \% \times 13 \%\end{array}$ & $\begin{array}{l}52 \times 60 \\
46 \% \times 54 \%\end{array}$ & $\begin{array}{l}112 \times 0 \\
100 \% \times 0 \%\end{array}$ & $\begin{array}{l}51 \times 61 \\
46 \% \times 54 \%\end{array}$ & $\begin{array}{l}98 \times 14 \\
88 \% \times 12 \%\end{array}$ & $\begin{array}{l}39 \times 73 \\
35 \% \times 65 \%\end{array}$ & $\begin{array}{l}102 \times 10 \\
91.1 \% \times 8.9 \%\end{array}$ & $\begin{array}{l}61 \times 51 \\
54.5 \% \times 45.5 \%\end{array}$ \\
\hline$p$-value* & 0.042 & 0.499 & 1 & 0.778 & 0.563 & 0.546 & 0.205 & 0.131 \\
\hline
\end{tabular}

$D D$ intervertebral disc degeneration

* Chi square test 
analysis. As the frequency of the BsmI genotypes deviated from Hardy-Weinberg equilibrium in both groups, it was not considered in the haplotype analysis. The results revealed that "TGT" haplotype (wild-type alleles of TaqI, ApaI and FokI polymorphisms) was less frequently in cases than controls, $15.1 \%$ of cases and $22.5 \%$ of control groups, $p=0.039$ (Table 4 ).

Finally, we tested the possible association among the VDR polymorphisms and the characteristics of the patients with disc degeneration, such as pain localization, smoking habits, engagement of physical activity, postural and load weight at work and familial history of the disease, but no association among them were found.

\section{Discussion}

Although the exact aetiology of degenerative disc is unknown, multifactorial conditions have been implicated in several studies. Probably, a complex interaction among environmental, genetic and biomechanical factors can create conditions that are favourable to the disc degeneration process [17].

In the population studied, smoking habits was identified as risk factor for disc degeneration. Complementary data revealed an inversely proportional relation between DD and school level. The proportion of individuals who load weight at work and presented low school level was statistically higher in the disc degeneration group; in other words, the more years of study, the lower load weight at work and the prevalence of disc degeneration as well. Musculoskeletal health depends on regular exercise [18], proper diet $[10,19]$ and maintenance of an appropriate body weight [20], although the long term effect of sustained extremes of exercise is not fully defined, either very high or very low loading, on the health of knees and the lower back [21]. Smoking habits induces biochemical stress in several tissues leading to endothelial lesions. In addition, there is an increase in catecholamines bringing on vasoconstriction, thus limiting oxygen supply, which may contribute to early degeneration of the intervertebral disc and bone demineralization [22]. A recent evidence [23] with a cohort of female twins found that modic changes exhibit a degree of heritability, indicating the potential involvement of genetic variants in the physiopathology of disc degeneration.

Furthermore, considering the VDR polymorphisms studied, TaqI polymorphism displayed a significant difference in the recessive model in the DD group, and the combination of wild-type alleles of TaqI, ApaI and FokI polymorphisms-TGT haplotype-was significantly frequent in controls, suggesting a lower risk of disc degeneration in carriers of these haplotypes.

Some authors explored the association between $V D R$ TaqI, BsmI, ApaI and FokI polymorphisms and disc degeneration, however the results were conflicting [10, 11, 24-27]. The divergent effects of these polymorphisms in DD development may be attributed, especially, to ethnic origin, once genetic ancestry among populations is responsible for different allelic frequencies, since mutations occurs randomly and are differently distributed around the world. Nevertheless, the age of the subjects studied (adults, young adults and adolescents) and sample size also should be considered.

Vitamin D receptor is involved in disc degeneration process indirectly, through its function within the chondrocyte [3]. The VDR gene plays a pleiotropic effect in bone mineralization [28] helping to control the calcium balance, and the differentiation, proliferation and maturation of chondrocytes, which in turn influencing the proteoglycan synthesis. The lumbar disc is rich in chondrocytes and proteoglycans. Therefore, small changes, such as common nucleotide substitutions, can alter the receptor's conformation or the gene

Table 4 Haplotype analysis of Taql, Apal and Fokl polymorphisms of the VDR gene regarding the frequency in the studied population and the $P$-value of each haplotype in disc degeneration group compared to controls

\begin{tabular}{|c|c|c|c|c|c|}
\hline \multicolumn{3}{|l|}{ Haplotype } & \multicolumn{2}{|c|}{ Disc degeneration } & \multirow{2}{*}{$\begin{array}{l}\text { Control group } \\
\text { Frequency (\%) }\end{array}$} \\
\hline Taql $(\mathrm{T}>\mathrm{C})$ & Apal $(\mathrm{G}>\mathrm{T})$ & Fokl $(\mathrm{T}>\mathrm{C})$ & Frequency (\%) & $p$-value* & \\
\hline $\mathrm{T}$ & T & T & 24.5 & 0.294 & 28.8 \\
\hline C & G & T & 20.5 & 0.741 & 19.3 \\
\hline T & G & T & 15.1 & 0.039 & 22.5 \\
\hline C & G & c & 12.2 & 0.561 & 10.5 \\
\hline T & G & c & 10.2 & 0.624 & 8.8 \\
\hline T & T & c & 9.9 & 0.226 & 6.8 \\
\hline C & T & T & 5.1 & 0.097 & 2.2 \\
\hline C & $\mathrm{T}$ & C & 2.5 & 0.243 & 1.1 \\
\hline
\end{tabular}

* Chi square test 
function, modifying vitamin D absorption activity, in this way, affecting the energetic balance exerted by vitamin $\mathrm{D}$ and parathyroid hormones in the intervertebral disc cells [8].

This study presents some limitations that need to be mentioned: (i) only four VDR SNPs were investigated and no functional study was performed; (ii) relative small sample size, which reduce the capacity of data extrapolation; (iii) difference in average age and gender between groups; (iv) no information about vitamin D levels of the participants, and (v) MRI not performed in the control group. However, the selection criteria of the participants were rigorous, including only symptomatic patients up to 45 years old with evident disc degeneration by MRI. In addition, although asymptomatic people may have disc degeneration and ideally the individuals selected for the control group should have undergone MRI to exclude the disease, the positive association between disc degeneration and low back pain has been confirmed in different population-based cohorts of adults, young adults and adolescents [29]. Disc degeneration may be due to a simple aging process and abnormalities of the lumbar spine by MRI examination can be meaningless if considered in isolation [30]. All participants of the control group who reported pain episodes in the spinal region, with previous history of disc hernia treatment, who have been hospitalized for back pain or have been reported positive familial history of disc herniation and/or clinical treatment for low back pain were excluded from the study. Moreover, different studies have not identified a significant influence of gender on the intervertebral degenerative process [31-33].

\section{Conclusion}

The findings suggest that smoking habits was a risk factor for disc degeneration in the population studied. Single analysis revealed no significant effects of $V D R$ polymorphisms in disc degeneration process, while the combination of wild-type alleles of TaqI, ApaI and FokI polymorphisms, TGT haplotype, decreased the risk of the disease.

\section{Authors' contributions}

$L A V, B B$ and LMRR conceived study design. AAS performed the data collection. $A A S, C P$ and $B B$ analysed data. LAV, AAS and BB interpreted data. All authors were involved in literature search, in paper writing and all of them had final approval of the submitted and published versions. All authors read and approved the final manuscript.

\footnotetext{
Author details

${ }^{1}$ Discipline of Orthopaedics and Traumatology, Department of Surgery, Faculdade de Medicina do ABC, Santo André, Brazil. ${ }^{2}$ Laboratory of Genetics, Human Reproduction and Genetics Center, Faculdade de Medicina do ABC, Av. Lauro Gomes, 2000, Santo André, SP CEP 09060-870, Brazil. ${ }^{3}$ Discipline of Sexual and Reproductive Health, and Populational Genetics, Department of Collective Health, Faculdade de Medicina do ABC, Santo André, Brazil.
}

Acknowledgements

We would like to thank Dr. Fernando Adami and Winter Figueiredo for their helping in statistical analysis.

\section{Competing interests}

The authors declare that they have no competing interests.

\section{Availability of data and materials}

The datasets used and/or analysed during the current study are available from the corresponding author on reasonable request.

\section{Consent for publication}

Not applicable.

\section{Ethics approval and consent to participate}

This study was approved by Faculdade de Medicina do ABC institutional ethics committee (CAAE08582212.6.0000.0082) and all participants signed a written consent to participate.

\section{Funding}

This work was supported by FAPESP research Grant \#13/00902-4.

\section{Publisher's Note}

Springer Nature remains neutral with regard to jurisdictional claims in published maps and institutional affiliations.

Received: 31 October 2017 Accepted: 13 February 2018

Published online: 21 February 2018

\section{References}

1. McCann MR, Patel P, Frimpong A, Xiao Y, Siqueira W, Seguin CA. Proteomic signature of the murine intervertebral disc. PLoS ONE. 2015;2:e0117807.

2. Martirosyan NL, Patel AA, Carotenuto A, et al. Alterations in intervertebral disc disease. Front Surg. 2016;3:e59.

3. Yuan HY, Tang Y, Liang YX, et al. Matrix metalloproteinase-3 and vitamin d receptor genetic polymorphisms, and their interactions with occupational exposure in lumbar disc degeneration. J Occup Health. 2010;52(1):23-30.

4. Battie MC, Videman T, Levalahti E, Gill K, Kaprio J. Genetic and environmental effects on disc degeneration by phenotype and spinal level: a multivariate twin study. Spine (Phila Pa 1976). 2008;33(25):2801-8.

5. Kelempisioti A, Eskola PJ, Okuloff A, et al. Genetic susceptibility of intervertebral disc degeneration among young finnish adults. BMC Med Genet. 2011;12:153.

6. Bischoff-Ferrari HA, Willett WC, Wong JB, Giovannucci E, Dietrich T, Dawson-Hughes B. Fracture prevention with vitamin D supplementation: a meta-analysis of randomized controlled trials. JAMA. 2005;293:2257-64.

7. Anderson PH, Lam NN, Turner AG, et al. The pleiotropic effects of vitamin D in Bone. J Steroid Biochem Mol Biol. 2013:136:190-4.

8. Yoshida T, Stern PH. How vitamin D works on bone. Endocrinol Metab Clin North Am. 2012:41:557-69.

9. Conti V, Russomanno G, Corbi G, et al. A polymorphism at the translation start site of the vitamin $\mathrm{D}$ receptor gene is associated with the response to anti-osteoporotic therapy in postmenopausal women from Southern Italy. Int J Mol Sci. 2015:16:5452-66.

10. Videman T, Leppavuori J, Kaprio J, Battié M, Koskenvuo M. Intragenic polymorphisms of the vitamin $D$ receptor gene associated with intervertebral disc degeneration. Spine. 1998;23:2477-85.

11. Pabalan N, Tabangay L, Jarjanazi H, et al. Association between the Fok and Apal polymorphisms in the vitamin D receptor gene and intervertebral disc degeneration: a systematic review and meta-analysis. Genet Test Mol Biomarkers. 2017:21:24-32.

12. Wang S, Ray N, Rojas W, et al. Geographic patterns of genome admixture in Latin American mestizos. PLoS Genet. 2008:4(3):e1000037.

13. Salzano F, Sans M. Interethnic admixture and the evolution of Latin American population. Genet Mol Biol. 2014:37(Suppl 1):151-70. 
14. Pfirrmann CW, Metzdorf A, Zanetti M, Hodler J, Boos N. Magnetic resonance classification of lumbar intervertebral disc degeneration. Spine (Phila Pa 1976). 2001;6(17):1873-8.

15. Vilarino FL, Bianco B, Lerner TG, et al. Analysis of vitamin D receptor gene polymorphisms in women with and without endometriosis. Hum Immunol. 2011;72:359-63.

16. Lahiri DK, Nurnberger JIJr. A rapid non-enzymatic method for the preparation of HMW DNA from blood for RFLP studies. Nucleic Acids Res. 1991;19:5444

17. Gologorsky Y, Chi J. Genetic predisposition to lumbar disc degeneration. Neurosurgery. 2014;74:10-1.

18. O'Donovan G, Blazevich AJ, Boreham C, et al. The ABC of physical activity for health: a consensus statement from the British association of sport and exercise sciences. J Sports Sci. 2010;28(6):573-91.

19. Francis RM. What do we currently know about nutrition and bone health in relation to United Kingdom public health policy with particular reference to calcium and vitamin D? Br J Nutr. 2008;99(1):155-9.

20. Lidstone JS, Ells LJ, Finn P, Whittaker VJ, Wilkinson JR, Summerbell CD. Independent associations between weight status and disability in adults: results from the Health Survey for England. Public Health. 2006;120(5):412-7.

21. Milgrom Y, Milgrom C, Constantini N, Applbaum Y, Radeva-Petrova $D$, Finestone AS. The effect of very high versus very low sustained loading on the lower back and knees in middle life. Biomed Res Int. 2013;2013:921830.

22. Vogt MT, Hanscom B, Lauerman WC, Kang JD. Influence of smoking on the health status of spinal patients: the National Spine Network database. Spine (Phila Pa 1976). 2002;27(3):313-9.

23. Määttä $J H$, Kraatari $M$, Wolber L. Vertebral endplate change as a feature of intervertebral disc degeneration: a heritability study. Eur Spine J. 2014:23:1856-62.

24. Kawaguchi $Y$, Kanamori M, Ishihara H, Ohmori K, Matsui H, Kimura T. The association of lumbar disc disease with vitamin-D receptor gene polymorphism. J Bone Joint Surg Am. 2002;84:2022-8.
25. Zawilla NH, Darweesh H, Mansour N, et al. Matrix metalloproteinase-3, vitamin D receptor gene polymorphisms, and occupational risk factors in lumbar disc degeneration. J Occup Rehabil. 2014;2:370-81.

26. Zhao J, Yang M, Shao J, Bai Y, Li M. Association between VDR FOKI polymorphism and intervertebral disc degeneration. Genomics Proteomics Bioinform. 2015;13:371-6.

27. Toktas ZO, Eksi MS, Yilmaz B, et al. Association of collagen I, IX and vitamin $D$ receptor gene polymorphisms with radiological severity of intervertebral disc degeneration in Southern European Ancestor. Eur Spine J. 2015;11:2432-41.

28. Colombini A, Brayda-Bruno M, Lombardi G, et al. Fokl polymorphism in the vitamin D receptor gene (VDR) and its association with lumbar spine pathologies in the italian population: a case-control study. PLoS ONE. 2014:5:e97027.

29. Eskola PJ, Kjaer P, Daavittila IM, et al. Genetic risk factors of disc degeneration among 12-14-year-old Danish children: a population study. Int J Mol Epidemiol Genet. 2010;1(2):158-65.

30. Jensen MC, Brant-Zawadzki MN, Obuchowski N, et al. Magnetic resonance imaging of the lumbar spine in people without back pain. N Engl J Med. 1994:331:69-73.

31. Siemionow K, An H, Masuda K, et al. The effects of age, sex, ethnicity, and spinal level on the rate of intervertebral disc degeneration: a review of 1712 intervertebral discs. Spine (Phila Pa 1976). 2011;36(17):1333-9.

32. Farshad-Amacker NA, Hughes AP, Aichmair A, et al. Determinants of evolution of endplate and disc degeneration in the lumbar spine: a multifactorial perspective. Eur Spine J. 2014;23:1863-8.

33. Gübitz R, Lange T, Gosheger G, et al. Influence of age, BMI, gender and lumbar level on T1 $\rho$ magnetic resonance imaging of lumbar discs in healthy asymptomatic adults. Rofo. 2018;190(2):144-51.

\section{Submit your next manuscript to BioMed Central and we will help you at every step:}

- We accept pre-submission inquiries

- Our selector tool helps you to find the most relevant journal

- We provide round the clock customer support

- Convenient online submission

- Thorough peer review

- Inclusion in PubMed and all major indexing services

- Maximum visibility for your research

Submit your manuscript at www.biomedcentral.com/submit
O Biomed Central 